\title{
Diagnostic and Prognostic Value of Nuclear Factor Kappa-B in Diffuse Large B Cell Lymphoma in Egyptian Patients with Hepatitis C Virus Genotype 4
}

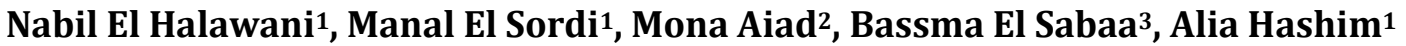 \\ ${ }^{1}$ Internal Medicine Department, Faculty of Medicine, Alexandria University, Alexandria, Egypt \\ ${ }^{2}$ Clinical Pathology Department, Faculty of Medicine, Alexandria University, Alexandria, Egypt \\ ${ }^{3}$ Pathology Department, Faculty of Medicine, Alexandria University, Alexandria, Egypt \\ Email: alia_awadh557@hotmail.com
}

How to cite this paper: El Halawani, N., El Sordi, M., Aiad, M., El Sabaa, B. and Hashim, A. (2019) Diagnostic and Prognostic Value of Nuclear Factor Kappa-B in Diffuse Large B Cell Lymphoma in Egyptian Patients with Hepatitis C Virus Genotype 4. American Journal of Molecular Biology, 9, 121-143.

https://doi.org/10.4236/ajmb.2019.93010

Received: May 14, 2019

Accepted: July 28, 2019

Published: July 31, 2019

Copyright $\odot 2019$ by author(s) and Scientific Research Publishing Inc. This work is licensed under the Creative Commons Attribution International License (CC BY 4.0).

http://creativecommons.org/licenses/by/4.0/

\begin{abstract}
Background: Members of the $\mathrm{NF} \kappa \mathrm{B}$ [p65] family have potential diagnostic and prognostic role in various inflammatory diseases and Lymphomas. Aim: We studied $\mathrm{NF} \kappa \mathrm{B}$ [p65] in paraffin blocks of hepatitis-C-virus [HCV] positive genotype-4 and HCV negative diffuse large B-cell lymphoma [DLBCL] patients, aiming at identification of its differential expression and prognosis in DLBCL and its subtypes; GCB and ABC. This is to establish its relation to $\mathrm{HCV}$ infection and its role in lymphogenesis. Besides assessing the role of new directly acting antiviral drugs [Sofusbuvir/Ledipasvir] concomitantly administered to [CHOP] combination in HCV positive DLBCL. Subjects and Methods: $\mathrm{NF} \kappa \mathrm{B}$ [p65] expression was assessed using Anti-NF $\kappa \mathrm{B}$ [p65] antibody semi-quantitative technique in 30 newly diagnosed DLBCL patients [HCV positive [ $n=15]$, HCV negative $[n=15]$. Results: NF $\kappa B$ [p65] expression was higher in the HCV positive DLBCL patients than their HCV negative counterpart, with a positive correlation with the viral load $[\mathrm{r}=0.536, \mathrm{p}=$ 0.088]. NF $\kappa \mathrm{B}$ [p65] expression was significantly more frequently detected in the $\mathrm{ABC}$ subtype than GCB subtype $[\mathrm{p}=0.04]$. Patients who expressed $\mathrm{NF} \kappa \mathrm{B}$ [p65] had higher incidence of extranodal involvement, advanced stages, higher $\mathrm{LDH}$ levels and IPI score. Besides, the expression of $\mathrm{NF} \kappa \mathrm{B}[\mathrm{P} 65]$ revealed an inferior overall response $[\mathrm{OR}][\mathrm{p}=0.044]$. Higher complete response rates to $\mathrm{CHOP}$ concomitantly with antiviral [ledipasvir/sofosbuvir] were encountered in the $\mathrm{HCV}$ positive group. In $\mathrm{HCV}$ positive group, $\mathrm{NF} \kappa \mathrm{B}$ [P65] displayed a positive relationship with the viral load and liver enzymes $[p=0.04]$, besides an inverse relation with serum albumin. This raises the possibility that $\mathrm{NF} \kappa \mathrm{B}$ [p65] expression is suggestive of the hepatic necro-inflammation in HCV pa-
\end{abstract}


tients. The ABC group presented more in advanced stages than GCB. Higher frequency of the $A B C$ subgroup exhibited intermediate to high viral load, while it was less in the GCB. A statistically significant difference was found in the $\mathrm{NF} \kappa \mathrm{B}$ [p65] positive patients as regards MUM1 expression among the two groups [ $\mathrm{p} \leq 0.001]$. Double positive $[\mathrm{CD} 10+, \mathrm{MUM} 1+]$ and triple negative [CD10-, BCL6-, MUM1-] cases were encountered in the HCV positive group, and were characterized with a high $\mathrm{NF} \kappa \mathrm{B}$ [p65] expression. Conclusion: $\mathrm{NF} \kappa \mathrm{B}[\mathrm{p} 65]$ is expressed in patients with DLBCL, more frequently in $\mathrm{ABC}$ than in GCB subtypes. Expression of $\mathrm{NF} \kappa \mathrm{B}$ [p65] is associated with poor response to therapy in DLBCL. The NF $\kappa \mathrm{B}$ [p65] disclosed an increased expression in HCV positive DLBCL compared to HCV negative group. The viral load displayed a positive correlation with the $\mathrm{NF} \kappa \mathrm{B}$ [p65] expression. Simultaneous administration of DAAs in combination with CHOP disclosed a better response and high tolerability.

\section{Keywords}

Diffuse Large B-Cell Lymphoma, NF- $\kappa$ B, Hepatitis C Virus, Germinal Center-B, Activated B-Cell-Like, Antiviral Therapy

\section{Introduction}

DLBCL is the commonest form of B-NHL, and is characterized by clinical and genetic heterogeneity. In the "cell of origin" classification, two main subtypes of DLBCL have been identified, the germinal center B cell [GCB]-like DLBCL, and the activated $B$ cell $[A B C]$-like [1] Hepatitis $C$ virus is an endemic infection in Egypt, being the first in prevalence rate in the world. HCV contributes to Lymphogenesis by affecting many cellular responses, that being clinically shown by the increased incidence of B-NHL in HCV positive patients.

$\mathrm{NF}-\kappa \mathrm{B}$ [nuclear factor kappa-light-chain-enhancer of activated $\mathrm{B}$ cells] is a protein complex that controls transcription, cytokine production and anti-apoptosis. The NF- $\kappa \mathrm{B}$ is found in all cell types and is involved in cellular responses to viral antigens [2] [3]. NF- $\kappa$ B plays a critical role in regulating the activation and differentiation of innate immune cells [4].

$\mathrm{NF} \kappa \mathrm{B}[\mathrm{p} 65]$ has been linked to diffuse large $\mathrm{B}$ cell lymphoma in many publications. The activation of NF- $\kappa \mathrm{B}$ is regulated by two distinct pathways termed the "canonical" and the "non-canonical" NF- $\kappa$ B signalling pathways [5], while the classical NF- $\kappa$ B activation pathway involves dimerization of p50 and p65. Those dimers are held inactive in the cytoplasm by specific inhibitors known as the inhibitor of $\kappa \mathrm{B}[\mathrm{I} \kappa \mathrm{B}]$ protein. $\mathrm{I} \kappa \mathrm{B}$ kinase phosphorylates the NF- $\kappa \mathrm{B}$-bound $\mathrm{I} \kappa \mathrm{Bs}$, which targets the $\mathrm{I} \kappa \mathrm{Bs}$ for ubiquitin-dependent degradation and allows the p65/p50 complex to translocate to the nucleus and initiate transcription of target genes. The p65/p50 pathway has been shown to promote inflammation, cellular proliferation and survival through the anti-apoptotic effect and to contribute to angiogenesis and tumor progression [6]. 
Toll-Like Receptors provide a bridge between innate and adaptive immunity. Immune responses are critically important in viral infections, including HCV infection [7]. The TLR1, TLR2 and TLR6 act as pattern receptors for HCV core and NS3 mediating myeloid differentiation primary response gene 88 [MyD88] activation, which leads to nuclear translocation of nuclear factor kappa-light-chain-enhancer of activated B cells [NF- $\kappa$ B] [8]. It was also shown that HCV leads to the inactivation of A20 that inhibits NF- $\kappa$ B, causing subsequent activation of NF- $\kappa$ B by increasing nuclear translocation in DLBCL [9].

MicroRNAs [miRNAs] play a role in controlling various biological functions, including cell differentiation, growth regulation and transcriptional regulation. $\mathrm{HCV}$ has been shown to influence miRNA expression in vivo and in vitro and utilizes the liver-specific microRNA miR-122 for its replication. The expression of miRNAs is also known to involve NF- $\kappa$ B activation. For example, miR-125a and miR-125b, both of which are often duplicated and/or over expressed in DLBCL, were shown to activate NF- $\kappa$ B by targeting the A20 and NF- $\kappa$ B mediated dysregulation of miRNAs observed in lymphoma [5].

In DLBCL, The expression of NF- $\kappa$ B pathway related genes differ between subtypes, establishing their molecular classification. It's suggested that ABC-DLBCL is driven by an abnormally high NF- $\kappa \mathrm{B}$ activity that deregulates expression of Bcl-2 family proteins, and is associated with inferior outcomes when compared to GCB-DLBCL [10]. Many publications have described p65 as an independent predictor of survival in high risk ABC DLBCL [11]. Constitutive NF- $\kappa$ B activation is due to several distinct genetic alterations in ABC-DLBCL. In this subtype, both positive and negative regulators of this pathway are affected, such as [BCR] signaling pathway, oncogenic CARD11, MYD88 mutations, and A20 inhibitor protein mutation [12] [13].

The role of Antiviral therapy has been well established in the outcome of HCV-related lymphoma demonstrated by that the anti-lymphoma activity of [AVT] Antiviral therapy is associated closely with the efficacy of AVT to achieve Sustained virological response [SVR]. This supports the assumption of a causal relationship between HCV and lymphomagenesis, as successful AVT is able to cure the lymphoma. The close correlation of SVR and lymphoma regression is a strong indicator that successful eradication of the virus is essential for the tumour response [14].

\section{Patients and Methods}

This study included thirty patients with newly diagnosed diffuse large B cell lymphoma admitted to the Hematology unit or presented to the hematology and Medical Oncology outpatient clinics at the Alexandria Main University Hospital. The diagnosis of DLBCL was done by applying the criteria of the WHO classification of tumors of the hematopoietic and lymphoid tissues 2016. Fifteen patients were selected to have Hepatitis C Virus, measured by detection of RNA and quantification by RT-PCR, and fifteen patients were HCV negative as a control group. All The laboratory investigations and bone marrow examination 
were done at the clinical pathology department, and the histopathological examination of samples was performed in the pathology department. The selected group had an Age range between 18 - 59 years, the studied patients $[n=30]$ aged 20 to 59 years of age with a mean of $44.93 \pm 11.35$ years. Among the studied patients 18 were males [60\%] and 12 females [40\%] with a male to female ratio of 1.5:1 and were characterized with having ECOG score of 2 or less. The samples were collected over a period of 16 months starting from April 2017 till 2018. Before starting chemotherapy, criteria of the International Prognostic Index was applied on the studied patients as a prognostication method. Child Pugh score was calculated at initial diagnosis for the HCV positive group and patient with decompensated liver failure were excluded from the selection process.

All cases in the study performed Anti-HCV antibodies serology through Enzyme Linked Immunosorbant Assay [ELISA] technique at the start of the study. HCV antibodies ELISA kit [Abnova] was used, and HCV genetic detection and quantification by polymerase chain reaction [PCR] by HCV RNA Quantification Assay Roche COBAS ${ }^{\circledR}$ Ampliprep Total Nucleic Acid Isolation Kit [TNAI] were performed in patients with positive serology. HCV genotype was determined using the polymerase chain reaction [PCR] amplification of the core region of the HCV genome by means of genotype-specific PCR primers. Patients included in this study were of the Genotype 4, other genotypes were excluded.

Biopsy material [excision or true cut] was obtained before treatment from lymph nodes in 21 cases [70\%], subcutaneous scalp mass in one case [3.33\%] mass at the base of the tongue in one case [3.33\%]. Computed Tomography [CT] guided core biopsy from abdominal lymph node/mass was performed in 5 cases [16.66\%]. Computed Tomography [CT] guided core biopsy from a hepatic focal lesion was done in two case [3.33\%].

DLBCL was diagnosed on H\&E and immunohistochemical basis employing the World Health Organization Classification 2016 [15]. Bone marrow trephine biopsy was performed in all cases for staging purposes, and was repeated after treatment in cases proven to be DLBCL with bone marrow infiltration. Radiological assessment in the form of Computed Tomography [CT] scan of the neck, chest, abdomen and pelvis was performed and all patients were staged according to the Ann Arbor staging system, and was repeated at the end of therapy.

All the patients received the following chemotherapy protocol [16]:

CHOP [Cyclophosphamide $750 \mathrm{mg} / \mathrm{m}^{2}$ dayl, Doxorubicin $50 \mathrm{mg} / \mathrm{m}^{2}$ dayl, Vincristine $1.4 \mathrm{mg} / \mathrm{m}^{2}$ [max.2 mg] day 1 , Prednisolone $50 \mathrm{mg} / \mathrm{m}^{2}$ day $\left.1-5\right]$ and the protocol were repeated every 21 days. Rituximab was given to the HCV negative group. Concomitant administration of directly acting Antiviral [DAA] Therapy for three months duration of ledipasvir [90 mg]/sofosbuvir [400 mg] was done in all HCV positive patients based on AASD treatment recommendations for HCV genome 4 [17].

Patients were re-assessed after 4 cycles of CHOP chemotherapy by clinical examination, laboratory investigations and Computed Tomography. All the pa- 
tients were evaluated for chemotherapy toxicity based on standard National Cancer Institute-World Health Organization [NCI-WHO] common toxicity criteria grading scale. Patients' response was assessed by Lugano criteria for response to DLBCL. HCV RNA Quantification Assay for Hepatitis C Virus was measured in follow up after 12 weeks of treatment to identify response to antiviral treatment. An HCV viral load below the lower limit of detection was considered as undetectable.

The study was permitted by the Ethics Committee of Alexandria Faculty of Medicine. An informed consent was obtained from all participants.

\subsection{Immunohistochemistry}

$3 \mu \mathrm{m}$ thick paraffin sections were prepared for immunohistochemical staining. Antibodies against CD3, CD20, CD15 and CD30 were employed for immunohistochemical diagnosis of DLBCL.

Further classification of DLBCL based on cell of origin into GCB and ABC subtypes was done using the histomorphological criteria proposed by the WHO Classification of Tumors of the Hematopoietic and Lymphoid Tissues 2016 [15]. Followed by application of Han's Algorithm [18] through immunohistochemistry as displayed in Table 1.

The immunostaining procedure was conducted in an automated platform employing Ventana Benchmarck GX apparatus. The procedure entailed the following steps:

1) Paraffin tissue sections were dewaxed and rehydrated;

2) Antigen retrieval using Ventana Benchmarck GX target retrieval solution;

3) Sections were cooled and treated with the Ventana Benchmarck GX peroxidase blocking reagent solution for 5 minutes;

Table 1. Immunohistochemical testing.

\begin{tabular}{|c|c|c|c|c|c|}
\hline Antibody & Manufacturer & Catalog No. & Clone & Dilution & Expected reactivity \\
\hline CD3 & $\begin{array}{l}\text { Thermo Fisher } \\
\text { Scientific, UK }\end{array}$ & $14-0031-82$ & PS1 & Assay dependant & Membranous \\
\hline CD15 & Thermo Fisher Scientific, UK & MA1-26893 & MMA; same asLeuM1 & $1: 100$ & $\begin{array}{l}\text { Surface membrane, } \\
\text { paranuclear }\end{array}$ \\
\hline CD30 & Thermo Fisher Scientific, UK & MA5-13219 & Ber-H2 & $1: 40-1: 80$ & Membrane and cytoplasmic \\
\hline $\mathrm{CD} 20$ & Thermo Fisher Scientific, UK & PA5-16701 & L26 & $1: 300$ & Membranous \\
\hline $\begin{array}{l}\text { CD10 } \\
\text { Rabbit Monoclonal } \\
\text { Antibody }\end{array}$ & Roche, USA & $790-4506$ & SP67 & $\begin{array}{l}\text { Specific antibody } \\
\text { concentration is } \\
\text { approximately } 4.9 \mu \mathrm{g} / \mathrm{mL}\end{array}$ & $\begin{array}{l}\text { Membranous, } \\
\text { cytoplasmic }\end{array}$ \\
\hline $\begin{array}{l}\text { BCL6 Mouse } \\
\text { Monoclonal Antibody }\end{array}$ & Thermo Fisher Scientific, UK & \#MS-1114-S0 & $\begin{array}{l}\text { BL6.02; same as } \\
\text { PG-B6p }\end{array}$ & $1: 20$ & Nuclear \\
\hline MUM1 IRF4- & BIOCARE Medical, USA & CRM 352 A, B & BC5 & $1: 200$ & Nuclear \\
\hline $\mathrm{NF} \kappa \mathrm{B}[\mathrm{p} 65]$ & Medyasis, Trukey & $\begin{array}{l}\text { RM0338, } \\
\text { RM0338RTU7 }\end{array}$ & MD35R & $1: 100$ & Nucleus, cytoplasm \\
\hline
\end{tabular}

Table 1 Immunohistochemical markers used in Immunohistochemical classification of DLBCL into the two molecular subtypes; ABC and GCB. 
4) Sections were next incubated with the primary antibody in Ventana Benchmarck GX antibody diluent for 20 minutes;

5) Upon antibody incubation Ventana standard signal amplification was performed, ultra Washed, then counter-stainined with one drop of Hematoxylin for $4 \mathrm{~min}$ and one drop of bluing reagent for $4 \mathrm{~min}$;

6) For chromogenic detection ultra View Universal DAB Detection Kit [Ventana] was used;

7) The slides then were washed in water with a drop of dishwashing detergent and mounted.

\subsection{Interpretation of Results}

The positive cut-off for CD10, MUM1, BCL6 and NF $\kappa \mathrm{B}$ [p65] was considered to be $30 \%$ [18]. Hans's algorithm [18] was applied for the classification of cases into either GCB or ABC-like subgroups. Cases were considered to belong to the GCB subgroup if CD10 alone was positive. CD10 negative cases were further examined for BCL-6 expression. When the latter was negative, then the case was classified as “ABC" subtype, regardless of the expression of MUM1.

Cases with BCL-6 positivity were further stained for MUM1 expression. If MUM1 was negative, then the case was considered GCB, where as positive cases were allocated to the ABC subgroup.

\subsection{NF $\kappa$ B [p65] Expression Interpretation}

Nuclear staining in $30 \%$ or more of tumor cells was considered a positive result. In the positive cases the relative percentage of immunopositive cells in relation to the total number of target cells was assessed. Values were recorded as a numerical score in every $20 \%$ [1, 30\% - 49\%; 2, 50\% - 69\%; 3, 70\% and more]. Intensity of the staining was also evaluated, it was scored from 0 to 3 [0, negative; $1+$, weak positive; $2+$, moderate positive; and $3+$, strong positive]. The final immunoscore was calculated by multiplying the percentage of positive cells $[\mathrm{P}]$ by the intensity [I] [Formula: $\mathrm{Q}=\mathrm{P} \times \mathrm{I}$; Maximum $=300$ ].

No stain uptake or reactivity less than $30 \%$ of tumorous population deemed a case "negative".

\subsection{Statistical Analysis}

Results were analyzed using IBM SPSS software package version 20.0. [Armonk, NY: IBM Corp]. Qualitative data were described using number and percent. Quantitative data were described using range [minimum and maximum], mean, standard deviation and median.

The non-parametric Mann-Whitney test was used to compare quantitative variables across groups of patients. $\mathrm{P}$ Chi-square test was utilized For categorical variables, to compare between the two groups, and Fisher's Exact [FEP] or Monte Carlo [MCP] correction Were used for Correction for chi-square when more than $20 \%$ of the cells have expected count less than 5 . 
The score on the International Prognostic Index [IPI] was treated as a categorical variable: low [score of 0 or 1], intermediate [score of 2 or 3], or high [score of 4 or 5]. Correlations between quantitative variables were done using Spearman rank correlation test.

Student t-test and F-test [ANOVA] were used for normally distributed quantitative variables, for abnormally distributed quantitative variables, Kruskal Wallis test was used to compare between more than two studied groups.

\section{Results}

This study included 30 patients with de novo DLBCL, in which 15 patients were Hepatitis $\mathrm{C}$ virus Positive with genotype 4, and 15 patients were HCV negative.

\subsection{Histopathology}

Molecular subclassification was performed for the 30 patients and among the HCV negative group, $53.3 \%$ were of the GCB subtype [ $n=8$ ], while $46.7 \%$ were of the $A B C$ subtype [n $=7$ ], as shown in Figure 1 and Figures 2-4. Of which only one case was of the "triple negative" entity [CD10-, BCL6-, MUM1-].

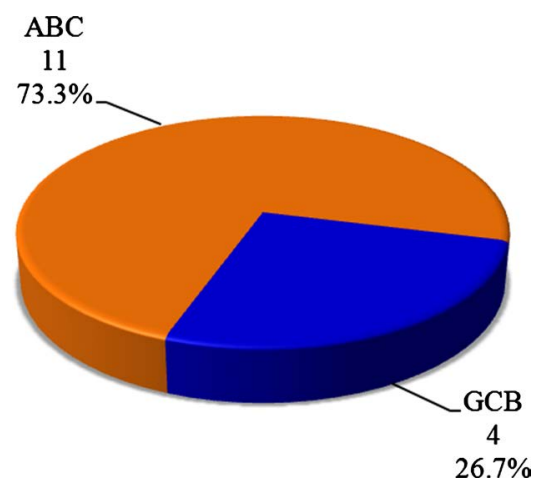

Figure 1. Distribution of the studied cases according to COO [cell of origin] in the HCV positive group $[\mathrm{n}=15]$.

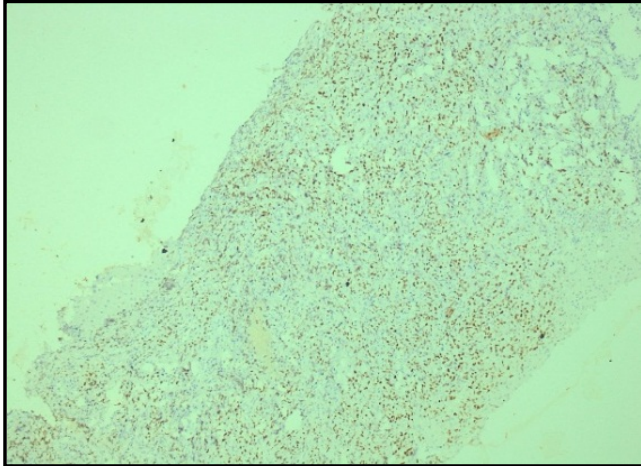

(a)

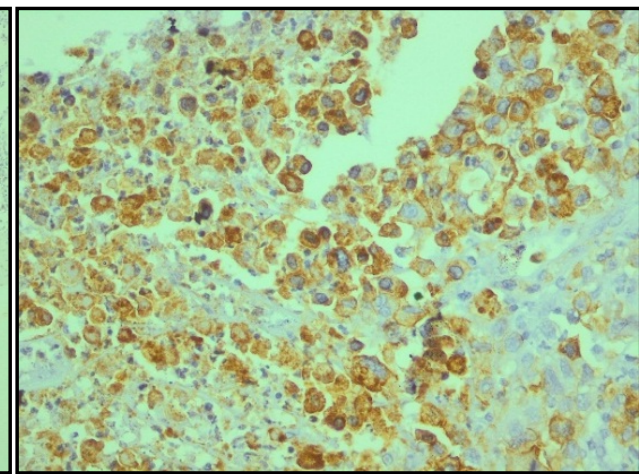

(b)

Figure 2. (a) High power of the Germinal centre B cell [GCB-DLBCL] featuring positive membranous and cytoplasmic expression of CD10, with immune reactivity in more than $30 \%$ of cellular population. [Anti-CD10, ×400]; (b) Intermediate power view of a case of GCB-DLBCL with positive BCL6 expression, with immunopositivity in more than $30 \%$ of the cells. [Anti-BCL6, $\times 200$ ]. 




(a)

(b)

Figure 3. (a)High power view of a case of GCB-DLBCL showing readily recognizable nuclear BCL6 expression [Anti-BCL6, $\times 400$ ]; (b) High power view of a case of GCB-DLBCL showing readily recognizable nuclear BCL6 expression [Anti-BCL6, ×400].

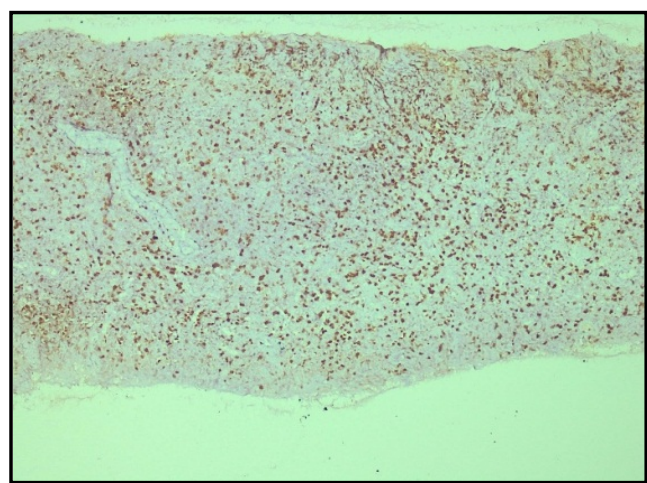

(a)

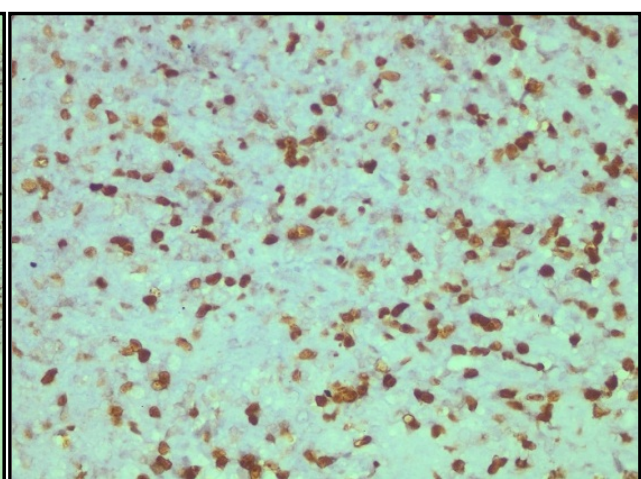

(b)

Figure 4. (a) Intermediate power view of an Activated B cell-Like [ABC] DLBCL, showing predominant strong nuclear expression of MUM1 with more than $30 \%$ of cells showing reactivity. [Anti-MUM1/IRF4, ×200]; (b) High power view of a case of Activated B cell-Like [ABC] DLBCL, showing strong nuclear expression of MUM1 with more than $30 \%$ of cells showing positive reactivity. [Anti-MUM1/IRF4, ×400].

Among the $\mathrm{HCV}$ positive group, $73.3 \%$ belonged to the ABC subtype [ $\mathrm{n}=11]$. 3 cases of them were "triple negative". GCB subtype was present in $26.7 \%$ of the group, of which two of these cases were of the Double positive [CD10+, MUM1+] entity.

\subsection{International Prognostic Scoring System, Performance Status and Staging of DLBCL Patients}

The HCV positive group showed higher IPI scores [60\% of patients presented with an IPI 3 [n $=9$ ] $26.7 \%$ had an IPI of $4[n=2]$, and only $13.3 \%$ of the patients had a low IPI of $2[\mathrm{n}=3$ ]. As for the HCV negative group, $33.3 \%$ of patients presented with an IPI score $1[n=5]$ and $20 \%$ of patients had an IPI of 2 $[\mathrm{n}=2]$, and $33.3 \%$ of patients presented with a higher IPI as $3[\mathrm{n}=5]$ and $13.3 \%$ had IPI of $4[\mathrm{n}=2]$. IPI showed statistical significance between the two groups $[\mathrm{p}=0.02]$. 
A statistically significant difference was detected between the ABC and GCB subtypes among the HCV Positive group as regards IPI [p $=0.05]$, where a high IPI was detected more in the ABC subtype [84\%] [n $=11]$ as shown in Table 2.

The ECOG performance score showed a statistically significant difference between the $\mathrm{ABC}$ and GCB subtypes among the HCV positive group [p $=0.010]$. The $\mathrm{ABC}$ group showed higher rate of presentation with ECOG score 1 were $81 \%$ of the group had such score [n $=9$ ], while $75 \%$ of the GCB group were presented with ECOG score 0 .

Two HCV positive DLBCL patients [13.3\%] were in early stage [I/II], as compared to their HCV negative control group which included 5 patients in the early stage [33.3\%]. In the HCV positive patients 13 cases [86.7\%] were in advanced stage [III/IV], while 10 patients [66.7\%] in the HCV negative group were in that advanced stage. It was found that $73 \%$ of the HCV positive group who presented with advanced stages $[n=13]$ as described by the Ann Arbor staging system were of the ABC subgroup [ $n=10]$ and $26 \%$ were GCB subtype [ $=3]$. While in the HCV negative group, $60 \%$ of the patients that presented with advanced stages [n=10] were GCB [n=6], compared to $40 \%$ from the ABC subtype [n=4].

Extranodal involvement of the disease was encountered in 93\%of the HCV positive group [ $n=14]$ and $60 \%$ in the HCV negative group $[n=9]$, with a $p$ value of [0.04].A significant difference is present between the HCV Positive and HCV negative groups $[\mathrm{p}=0.05]$ in BM infiltration.

\subsection{Chemotherapy and Response to Treatment}

All patients of two groups received 4 cycles of chemotherapy and were re-assessed both clinically and radiologically thereafter. One case died early in the study after receiving only two cycles of $\mathrm{CHOP}$.

As regards response in the HCV positive and negative groups, Complete response [CR] was encountered in $33.3 \%$ of the patients [ $n=5$ ], while $26.7 \%$ of the HCV negative group achieved CR after the course of treatment $[n=4]$. The

Table 2. Comparison between the HCV positive and HCV negative groups regarding the international prognostic index [IPI].

\begin{tabular}{|c|c|c|c|c|c|c|}
\hline \multirow{3}{*}{$\begin{array}{l}\text { International Prognostic } \\
\text { Index [IPI] }\end{array}$} & \multicolumn{4}{|c|}{$\mathrm{HCV}$} & \multirow{3}{*}{ Test of sig. } & \multirow{3}{*}{$\mathrm{p}$} \\
\hline & \multicolumn{2}{|c|}{ Negative $[n=15]$} & \multicolumn{2}{|c|}{ Positive [n $=15$ ] } & & \\
\hline & No. & $\%$ & No. & $\%$ & & \\
\hline 1 & 5 & 33.3 & 0 & 0.0 & \multirow{4}{*}{$\begin{array}{c}x^{2} \\
6.891\end{array}$} & \multirow{4}{*}{$\begin{array}{l}{ }^{\mathrm{MC}} \mathrm{p}= \\
0.093\end{array}$} \\
\hline 2 & 3 & 20.0 & 3 & 13.3 & & \\
\hline 3 & 5 & 33.3 & 9 & 60.0 & & \\
\hline 4 & 2 & 13.3 & 4 & 26.7 & & \\
\hline $1+2$ "low" & 8 & 53.3 & 2 & 13.3 & \multirow{2}{*}{$5.400^{\star}$} & \multirow{2}{*}{$0.020^{*}$} \\
\hline $3+4$ "High" & 7 & 46.7 & 13 & 86.7 & & \\
\hline
\end{tabular}

*: Statistically significant at $\mathrm{p} \leq 0.05$. 
overall response $[\mathrm{CR}+\mathrm{PR}]$ in the $\mathrm{HCV}$ negative group was $93.3 \%$, while in the $\mathrm{HCV}$ positive group it was $66.7 \%$. The $\mathrm{HCV}$ positive patients showed No response [CR + PR] in $26.7 \%$ of cases [ $=4$ ], while No response was encountered in only one case on the HCV negative group [6.7\%].

Among the ABC subtype, response varied according to the HCV status and treatment received. In the $\mathrm{HCV}$ positive $\mathrm{ABC} 36 \%$ of cases achieved $\mathrm{CR}$ [n=4], while in the HCV negative ABC group, none of the cases achieved such response. No response [PD + SD] was encountered in $16.7 \%$ of the cases among the HCV negative $\mathrm{ABC}$, while it was seen in $18.3 \%$ of the $\mathrm{HCV}$ positive $\mathrm{ABC}$ group.

In the $\mathrm{HCV}$ positive group, a median of $[3,310,000 \mathrm{ml}]$ was encountered in the cases with progressive course of disease, while it was less in patients who achieved CR [219,000 ml] and PR [41,500 ml].

\subsection{Laboratory}

The platelet count showed a significant difference with a $\mathrm{p}$ value of [0.027], as the mean platelet count in the HCV positive group was $124 \times 10^{9}$ compared to $193 \times 10^{9}$ in the HCV negative group. Pretreatment tranaminases were higher in the $\mathrm{HCV}$ positive group compared to $\mathrm{HCV}$ negative group with a median of 34.0 U/L. Total and direct Bilirubin were elevated in 6 patients, of which four had mild hepatic impairment and were managed with liver support. The $p$ value between the two groups as regards Bilirubin was $[\mathrm{p}=0.056]$ with a statistical significance. All patients were able to tolerate chemotherapy well without worsening hepatic condition (Table 3 ).

Albumin level showed a statistical significance between the two groups, were the median value in the HCV negative group was $[3.80 \mathrm{~g} / \mathrm{dl}]$ while in the HCV positive group $[3.0 \mathrm{~g} / \mathrm{dl}]$ with a $\mathrm{p}$ value of [0.001] prothrombin activity was reduced in the HCV positive group with a median of [77.0\%] while it was normal [90.0\%] in the HCV negative group, with a $\mathrm{p}$ value of [0.001].

In the GCB group, the low viral load was encountered in 2 cases [50\%], while the intermediate and high were seen in one case for each [25\%]. In the ABC group with HCV infection, low viral load was encountered in 4 cases [36\%], intermediate viral load [36.4\%], and high viral load was in 3 cases [27\%], as shown in Figure 5. The median viral load in the $\mathrm{ABC}$ group was $4.7 \times 10^{5}$, while the median in the GCB was $8.9 \times 10^{4}$.

\subsection{NF $\kappa$ B [p65] Expression}

Among the HCV negative group, the $\mathrm{NF} \kappa \mathrm{B}$ [p65] Expression was detected in $53.3 \%$ of the cases $[n=8]$. Meanwhile, in the HCV positive group $73 \%$ of the cases expressed NF $\kappa \mathrm{B}$ [p65] positivity [ $\mathrm{n}=11$ ] (Table 4 , and illustrated in Figure 6).

$\mathrm{NF} \kappa \mathrm{B}$ [p65] expression showed a statistically significant difference, where the $\mathrm{ABC}$ subtype was positive in $73.7 \%$ [ $\mathrm{n}=6$ ] of cases compared to $26.3 \%$ of GCB $[\mathrm{n}=2]$ subtype. $[\mathrm{p}=0.04]$.

Among the HCV positive group, $72 \%$ of the cases that expressed NF $\kappa \mathrm{B}$ [p65] 
were of the $A B C$ subtype, and $27 \%$ of the cases were GCB. Two of these cases were of the Double positive [DP: CD10, MUM1 positive] groups, as shown in Table 5 and illustrated in Figure 7.

Table 3. Comparison between the HCV positive and HCV negative groups regarding laboratory investigation.

\begin{tabular}{|c|c|c|c|c|}
\hline \multirow{2}{*}{ Laboratory investigation } & \multicolumn{2}{|c|}{$H C V$} & \multirow{2}{*}{ Test of sig. } & \multirow{2}{*}{$\mathrm{p}$} \\
\hline & Negative $[n=15]$ & Positive $[n=15]$ & & \\
\hline$\underline{C B C}$ & Mean \pm SD. & Mean \pm SD & & \\
\hline$H b[\mathrm{~g} / \mathrm{dl}]$ & $10.85 \pm 1.91$ & $10.23 \pm 1.65$ & $\mathrm{t}=0.941$ & 0.355 \\
\hline Platelets $\left[\times 10^{9}\right]$ & $224.5 \pm 86.40$ & $151.3 \pm 84.79$ & $\mathrm{t}=2.342^{\star}$ & $0.027^{\star}$ \\
\hline$W B C s\left[\times 10^{9}\right]$ & $7.98 \pm 4.18$ & $8.21 \pm 8.77$ & $\mathrm{U}=89.50$ & 0.345 \\
\hline \multicolumn{5}{|l|}{$\underline{\text { Renal function }}$} \\
\hline Urea & $32.53 \pm 10.93$ & $43.07 \pm 31.54$ & $\mathrm{U}=83.0$ & 0.233 \\
\hline Creatinine & $0.98 \pm 0.24$ & $1.0 \pm 0.58$ & $\mathrm{U}=86.0$ & 0.285 \\
\hline \multicolumn{5}{|l|}{ Liver function } \\
\hline$S G O T$ & $28.80 \pm 9.29$ & $42.73 \pm 27.35$ & $\mathrm{U}=64.50^{\star}$ & $0.045^{\star}$ \\
\hline$S G P T$ & $29.13 \pm 8.13$ & $94.47 \pm 241.37$ & $\mathrm{U}=75.50$ & 0.126 \\
\hline Total bilirubin & $1.29 \pm 1.66$ & $1.99 \pm 3.46$ & $\mathrm{U}=91.0$ & 0.389 \\
\hline Direct bilirubin & $0.59 \pm 1.45$ & $1.13 \pm 2.29$ & $\mathrm{U}=66.0$ & 0.056 \\
\hline$A l b$ & $3.81 \pm 0.38$ & $3.05 \pm 0.40$ & $\mathrm{t}=5.349^{*}$ & $<0.001^{*}$ \\
\hline$P T \%$ & $88.79 \pm 8.29$ & $74.20 \pm 13.74$ & $\mathrm{t}=3.521^{\star}$ & $0.001^{*}$ \\
\hline$E S R$ & $103.6 \pm 40.89$ & $104.7 \pm 33.73$ & $\mathrm{t}=0.078$ & 0.938 \\
\hline$L D H$ & $312.5 \pm 167.0$ & $436.7 \pm 320.5$ & $\mathrm{U}=88.0$ & 0.325 \\
\hline Uric Acid & $5.0 \pm 1.0$ & $5.40 \pm 1.45$ & $t=0.878$ & 0.387 \\
\hline
\end{tabular}

$*$ : Statistically significant at $\mathrm{p} \leq 0.05$.

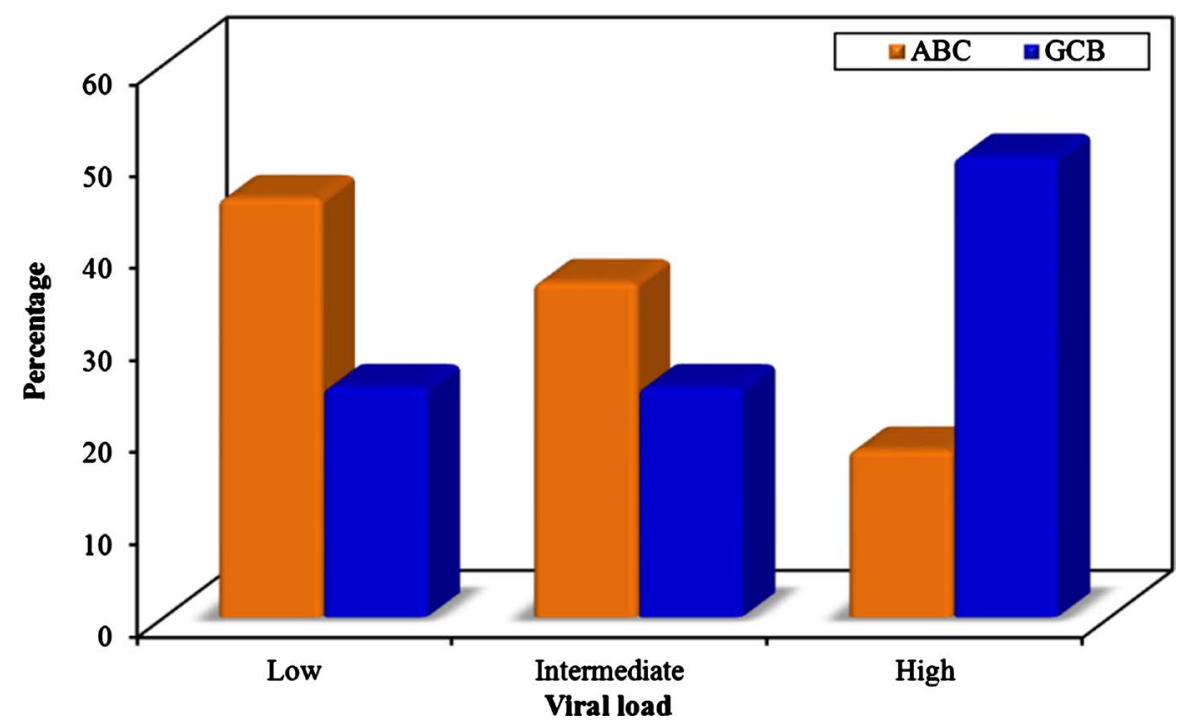

Figure 5. Relation between viral load and COO [cell of origin] in HCV positive [ $n=15]$. 
Table 4. Distribution of NF $\kappa B$ [p65] expression in the studied cases.

\begin{tabular}{ccc}
\hline NF $\boldsymbol{\kappa}$ B [p65] & No. & $\%$ \\
\hline HCV negative $[\mathrm{n}=15]$ & 7 & 46.7 \\
Negative & 8 & 53.3 \\
Positive & & \\
HCV positive $[\mathrm{n}=15]$ & 4 & 26.7 \\
Negative & 11 & 73.3 \\
Positive & & \\
Total cases [n $=30]$ & 11 & 36.7 \\
Negative & 19 & 63.3 \\
Positive & & \\
\hline
\end{tabular}

*: Statistically significant at $\mathrm{p} \leq 0.05$.

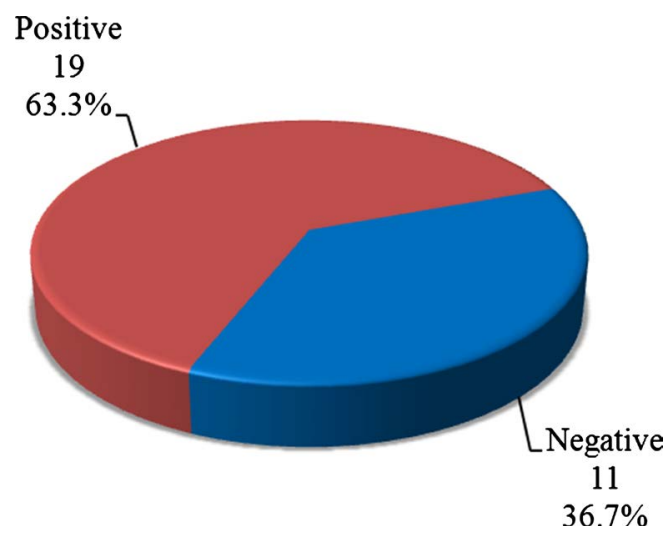

Figure 6. Distribution of the studied cases according to NF $\kappa$ B [p65] [n $=30]$.

Table 5. Relation between NF $\kappa$ B [p65] and COO [cell of origin].

\begin{tabular}{|c|c|c|c|c|c|c|}
\hline \multirow{3}{*}{$\mathrm{COO}$ [cell of origin] } & \multicolumn{4}{|c|}{$N F \kappa B[p 65]$} & \multirow{3}{*}{$x^{2}$} & \multirow{3}{*}{$\mathrm{p}$} \\
\hline & \multicolumn{2}{|c|}{ Negative $[n=7]$} & \multicolumn{2}{|c|}{ Positive $[n=8]$} & & \\
\hline & No. & $\%$ & No. & $\%$ & & \\
\hline \multicolumn{7}{|l|}{ HCV negative $[n=15]$} \\
\hline $\mathrm{ABC}$ & 1 & 14.3 & 6 & 75.0 & \multirow{2}{*}{$5.529^{*}$} & \multirow{2}{*}{${ }^{\mathrm{FE}} \mathrm{p}=0.041^{*}$} \\
\hline GCB & 6 & 85.7 & 2 & 25.0 & & \\
\hline \multicolumn{7}{|l|}{ HCV positive $[n=15]$} \\
\hline $\mathrm{ABC}$ & 3 & 75.0 & 8 & 72.7 & \multirow{2}{*}{0.008} & \multirow{2}{*}{${ }^{\mathrm{FE}} \mathrm{p}=1.000$} \\
\hline GCB & 1 & 25.0 & 3 & 27.3 & & \\
\hline \multicolumn{7}{|l|}{ Total cases $[\mathrm{n}=30]$} \\
\hline $\mathrm{ABC}$ & 4 & 36.4 & 14 & 73.7 & \multirow{2}{*}{$4.043^{*}$} & \multirow{2}{*}{$0.044^{*}$} \\
\hline GCB & 7 & 63.6 & 5 & 26.3 & & \\
\hline
\end{tabular}

$\chi^{2}$ : Chi square test; E: Fisher Exact; p: p value for comparing between the two categories; ${ }^{*}$ : Statistically significant at $\mathrm{p} \leq 0.05$. 
The double positive cases [CD10+, MUM1+], which are associated with a relatively more inferior response, were present among the HCV positive patients and had a marked Intensity of NF $\kappa B$ [p65] staining, and a high concentration [Q score $=225$ ]. The $\mathrm{NF} \kappa \mathrm{B}[\mathrm{p} 65]$ Q score was less elevated in the triple negative patients [Median Q score $=140$ ].

Among patients with $\mathrm{NF} \kappa \mathrm{B}$ [p65] expression, marked intensity in the $\mathrm{NF} \kappa \mathrm{B}$ [p65] IHC staining was detected in $63 \%$ of the HCV positive group, while it was seen in only $25 \%$ of the HCV negative group (Figure 8).

$\mathrm{NF} \kappa \mathrm{B}$ [p65] Expression was further examined for the concentration of positive cells in relation to the target population, as illustrated in Figure 9 and Figure 10. In the HCV positive group, $27 \%$ showed expression between $30 \%-50 \%, 18.2 \%$ showed a concentration between $50 \%-70 \%$, and $47 \%$ was with a concentration of

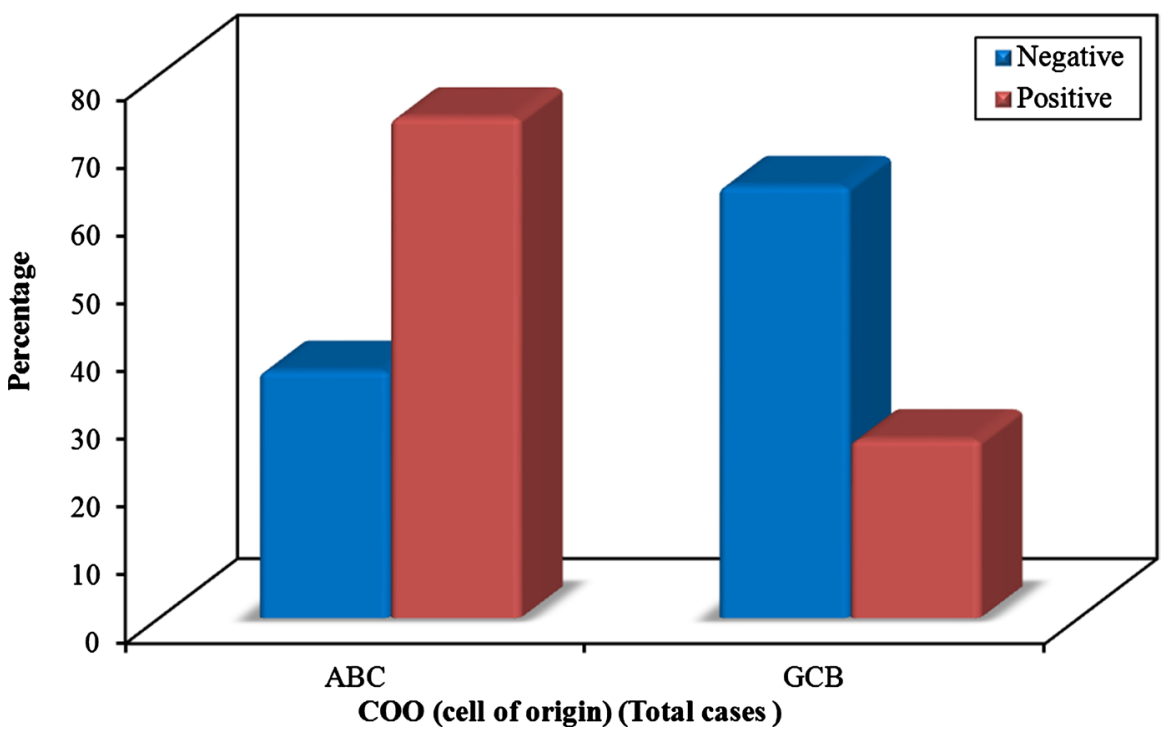

Figure 7. Relation between $\mathrm{NF} \kappa \mathrm{B}$ [p65] and $\mathrm{COO}$ [cell of origin] [Total cases [ $\mathrm{n}=30$ ]].

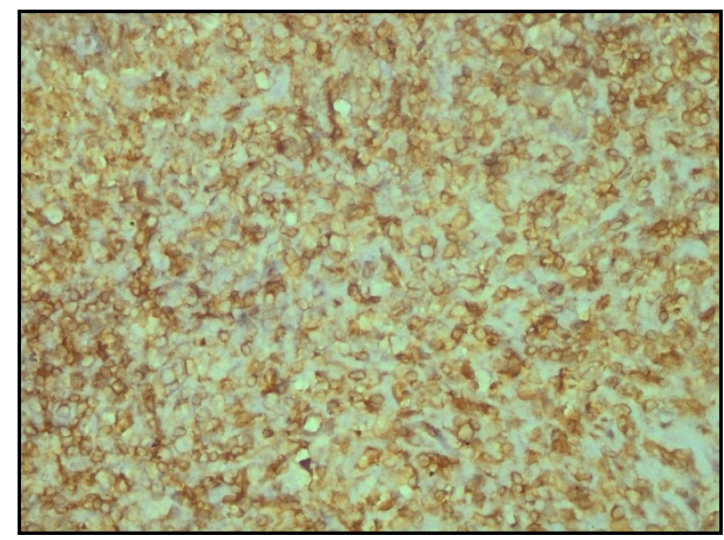

(a)

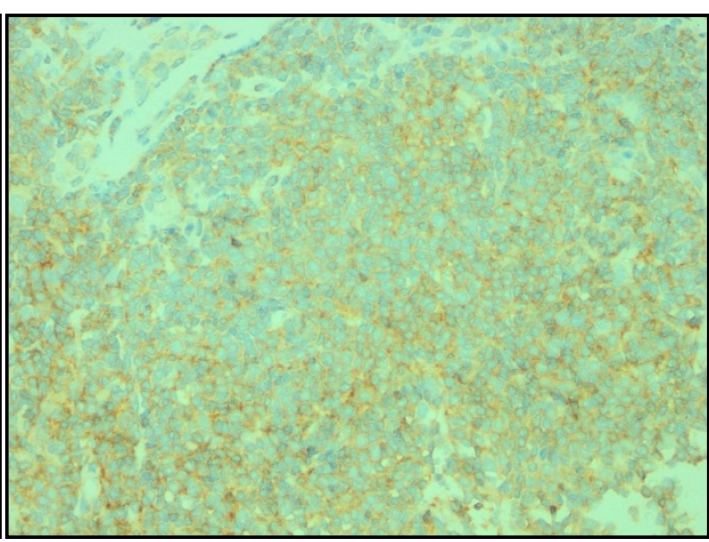

(b)

Figure 8. (a) High power view of a case of $\mathrm{NF} \kappa \mathrm{B}$ [p65] expression in an Activate B cell-like [ABC] DLBCL case showing cytoplasmic and nuclear expression. [Anti-NF $\kappa \mathrm{B}$ [p65], $\times 400$ ]; (b) High power view of a case of $\mathrm{NF} \kappa \mathrm{B}$ [p65] expression in a case of Activated B cell-like [ABC] DLBCL case showing cytoplasmic expression in more than $90 \%$ of target cells with moderate intensity. [Anti-NF $\kappa \mathrm{B}$ [p65], $\times 400$ ]. 


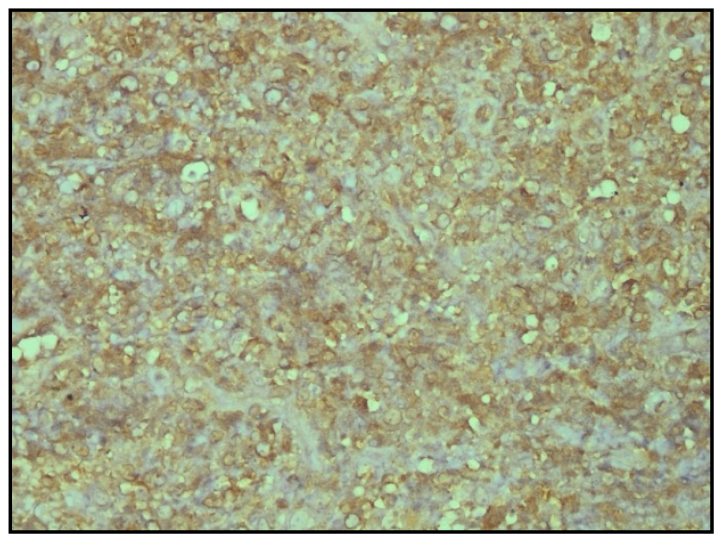

Figure 9. High power view of a case of a Germinal B cell [GCB] DLBCL case with NF $\kappa$ B [p65] expression showing cytoplasmic immunopositivity with more than $30 \%$ of the cells showing immunopositivty. [Anti-NF $\kappa$ B [p65], ×400].

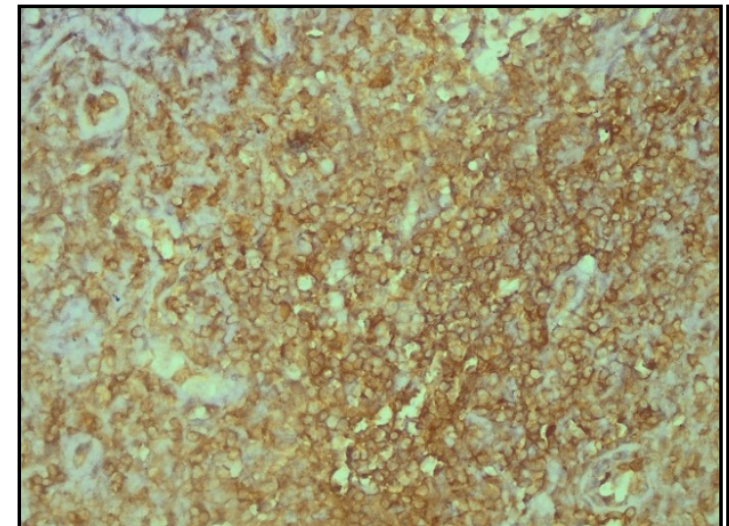

(a)

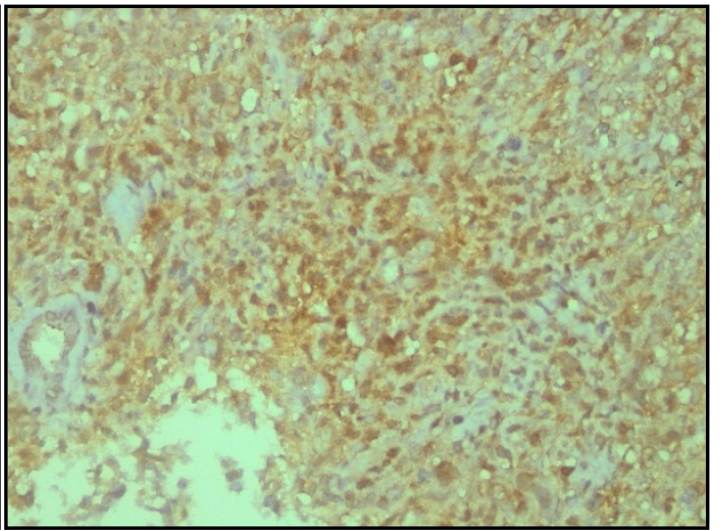

(b)

Figure 10. (a) High power view of a case of Germinal B cell [GCB] DLBC showing NF $\kappa$ B [p65] expression in a case showing nuclear expression with more than $30 \%$ of the cells showing immunopositivty. [Anti-NF $\kappa \mathrm{B}$ [p65], $\times 400$ ]; (b) High power view of a case of Activate B cell-like [ABC] DLBCL with NF $\kappa$ B [p65] expression in a case showing cytoplasmic and nuclear expression. [Anti-NF $\kappa \mathrm{B}[\mathrm{p} 65], \times 400]$.

$70 \%$ and more, being the highest in the group.

Among the patients with $\mathrm{NF} \kappa \mathrm{B}$ [p65] expression, the viral load was low in $27 \%[n=3$ ] of cases, $36 \%$ of cases were intermediate [ $n=4$ ], and $36 \%$ of cases had a high viral load $[n=4]$. The viral load was positively correlated to the concentration of $\mathrm{NF} \kappa \mathrm{B}$ [p65], a median viral load of [41,500 ml] was detected among the group with a concentration [30\%-50\%], a median of $[308,500 \mathrm{ml}]$ was among the group of [50\% - 70\%], and a higher viral load of [1,158,500 ml] was present in the group with more than $70 \%$ of $\mathrm{NF} \kappa \mathrm{B}[\mathrm{p} 65]$ concentration. There was a statistically non-significant positive correlation between $\mathrm{NF} \kappa \mathrm{B}$ [p65] intensity and HCV viral load in HCV positive group $[\mathrm{n}=11][\mathrm{r}=0.538, \mathrm{p}=$ 0.088] (Figure 11).

There was a statistically non-significant positive correlation between $\mathrm{NF} \kappa \mathrm{B}$ [p65] Q score and HCV viral load among patients with NF $k B$ [p65] expression $[\mathrm{n}=19],[\mathrm{r}=0.319, \mathrm{p}=0.339]$. 


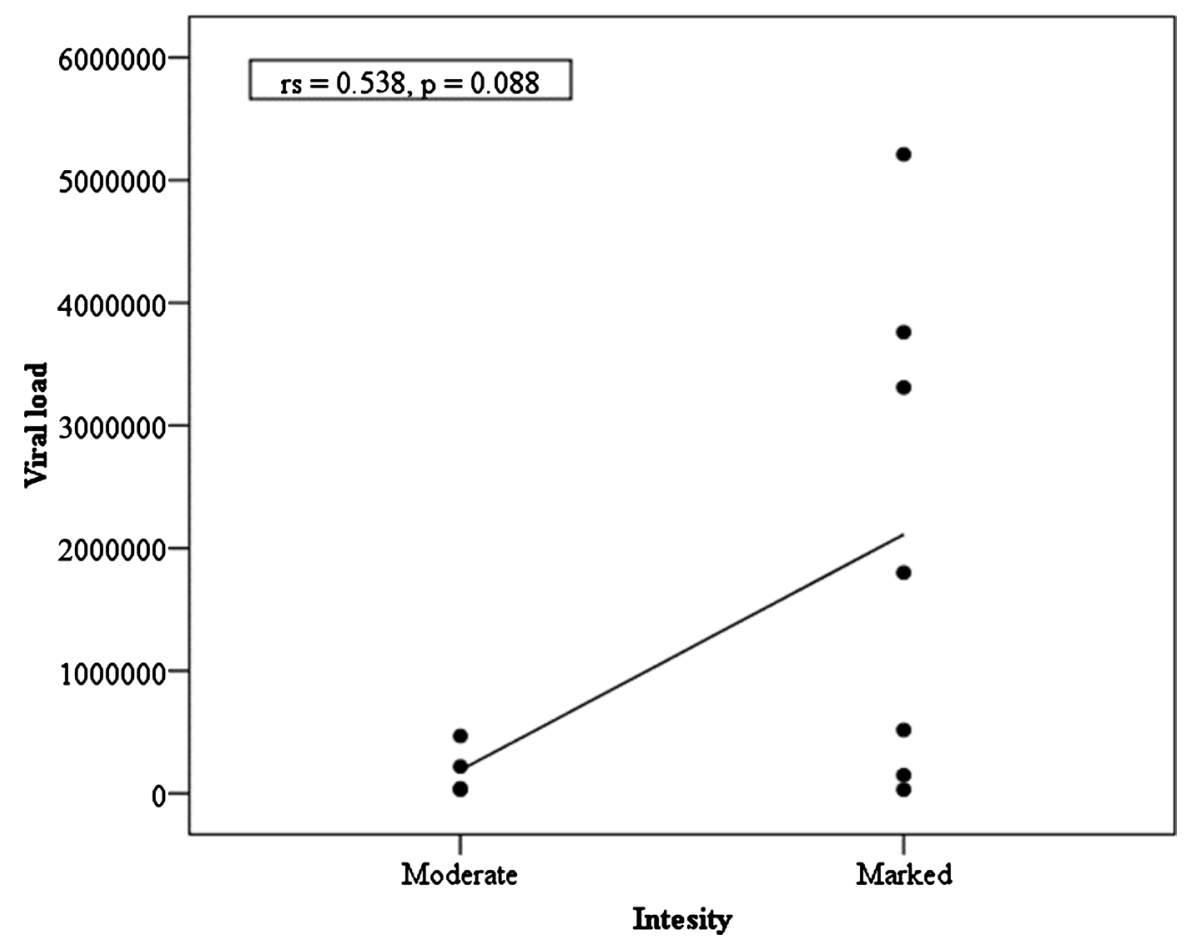

Figure 11. Correlation between intesity and viral load in positive HCV group $[\mathrm{n}=11]$ [p $=0.088$.

Marked intensity of staining among the HCV positive group [n $=7$ ] was higher than in the HCV negative group [ $=2]$, where most of the HCV negative group with $\mathrm{NF} \kappa \mathrm{B}$ [p65] expression showed moderate expression in immunohistochemical reactivity.

The mean $\mathrm{NF} \kappa \mathrm{B}$ [p65] Q score was slightly higher in ABC subtypes of DLBCL than the GCB subtype [172.14 \pm 72.87 vs $170.0 \pm 88.32]$, however that was statistically non-significant $[\mathrm{p}=0.964]$.

BCL6 showed positive expression in $40 \%$ of the HCV positive cases [n $=6]$, among them 5 patients had a positive $\mathrm{NF} \kappa \mathrm{B}[\mathrm{p} 65]$ expression in the HCV negative group, BCL6 was detected in 33\% of the cases [ $n=5]$, of them 2 cases had positive $\mathrm{NF} \kappa \mathrm{B}[\mathrm{p} 65]$ expression. In the $\mathrm{HCV}$ positive group, $\mathrm{CD} 10$ expression was encountered in $33 \%$ of the cases [ $n=5]$, and among them 4 patients had $\mathrm{NF} \kappa \mathrm{B}$ [p65] expression. In the HCV negative group, CD10 was detected in $46 \%$ of the cases [ $n=7$ ], among them 2 patients only showed NF $\kappa B$ [p65] expression.

A statistically significant relationship was found between the positivity of $\mathrm{NF} \kappa \mathrm{B}$ [p65] and MUM1 in HCV negative group and HCV positive groups as well as in the total studied group [ $\mathrm{p}=0.026, \mathrm{p}=0.026, \mathrm{p} \leq 0.001$ respectively], as shown in Table 6.

Extranodal involvement was higher among the group with $\mathrm{NF} \kappa \mathrm{B}$ [p65] Expression $84.2 \%[\mathrm{n}=19]$, and among the HCV group it was in $90.9 \%[\mathrm{n}=11]$ of the cases with positive $\mathrm{NF} \kappa \mathrm{B}$ [p65] expression, while in the HCV negative group it was $53 \%[n=6]$ More advanced stages presented more among the HCV positive patients with $\mathrm{NF} \kappa \mathrm{B}$ [p65] expression [69\%], compared to the cases that were 
negative to NF $\kappa \mathrm{B}$ [p65] [30\%]. The NF $\kappa \mathrm{B}$ [p65] Q score was higher in Late Ann Arbor patients $[\mathrm{n}=15$, mean $=172.67 \pm 77.96]$ than in early Ann Arbor patients $[\mathrm{n}=5$, mean $=167.50 \pm 70.89]$, but that was statistically non-significant $[\mathrm{p}=$ 0.885] (Figure 12).

In the $\mathrm{HCV}$ positive group, $\mathrm{NF} \kappa \mathrm{B}$ [p65] expression presented with a lower Albumin level [median 3.0], while in the HCV negative group it showed a median of [3.90]. NF $\kappa$ B [p65] expression showed an inverse relationship with Serum

Table 6. Relation between NF $\kappa$ B [p65] and MUM1.

\begin{tabular}{|c|c|c|c|c|c|c|}
\hline \multirow{3}{*}{ MUM1 } & \multicolumn{4}{|c|}{$\mathrm{NF} \kappa \mathrm{B}[\mathrm{p} 65]$} & \multirow{3}{*}{$x^{2}$} & \multirow{3}{*}{${ }^{\mathrm{FE}} \mathrm{p}$} \\
\hline & \multicolumn{2}{|c|}{ Negative } & \multicolumn{2}{|c|}{ Positive } & & \\
\hline & No. & $\%$ & No. & $\%$ & & \\
\hline HCV negative $[\mathrm{n}=15]$ & \multicolumn{2}{|c|}{$[\mathrm{n}=7]$} & \multicolumn{2}{|c|}{$[\mathrm{n}=8]$} & & \\
\hline Negative & 7 & 100.0 & 3 & 37.5 & \multirow{2}{*}{$6.563^{*}$} & \multirow{2}{*}{$0.026^{*}$} \\
\hline Positive & 0 & 0.0 & 5 & 62.5 & & \\
\hline HCV positive $[n=15]$ & \multicolumn{2}{|c|}{$[n=4]$} & \multicolumn{2}{|c|}{$[\mathrm{n}=11]$} & \multirow{3}{*}{$6.234^{*}$} & \multirow{3}{*}{$0.026^{*}$} \\
\hline Negative & 4 & 100.0 & 3 & 27.3 & & \\
\hline Positive & 0 & 0.0 & 8 & 72.7 & & \\
\hline Total cases $[n=30]$ & \multicolumn{2}{|c|}{$[\mathrm{n}=11]$} & \multicolumn{2}{|c|}{$[n=19]$} & & \\
\hline Negative & 11 & 100.0 & 6 & 31.6 & \multirow{2}{*}{$13.282^{*}$} & \multirow{2}{*}{$<0.001^{\star}$} \\
\hline Positive & 0 & 0.0 & 13 & 68.4 & & \\
\hline
\end{tabular}

$\chi^{2}$ : Chi square test; FE: Fisher Exact; ${ }^{*}$ : Statistically significant at $\mathrm{p} \leq 0.05$.

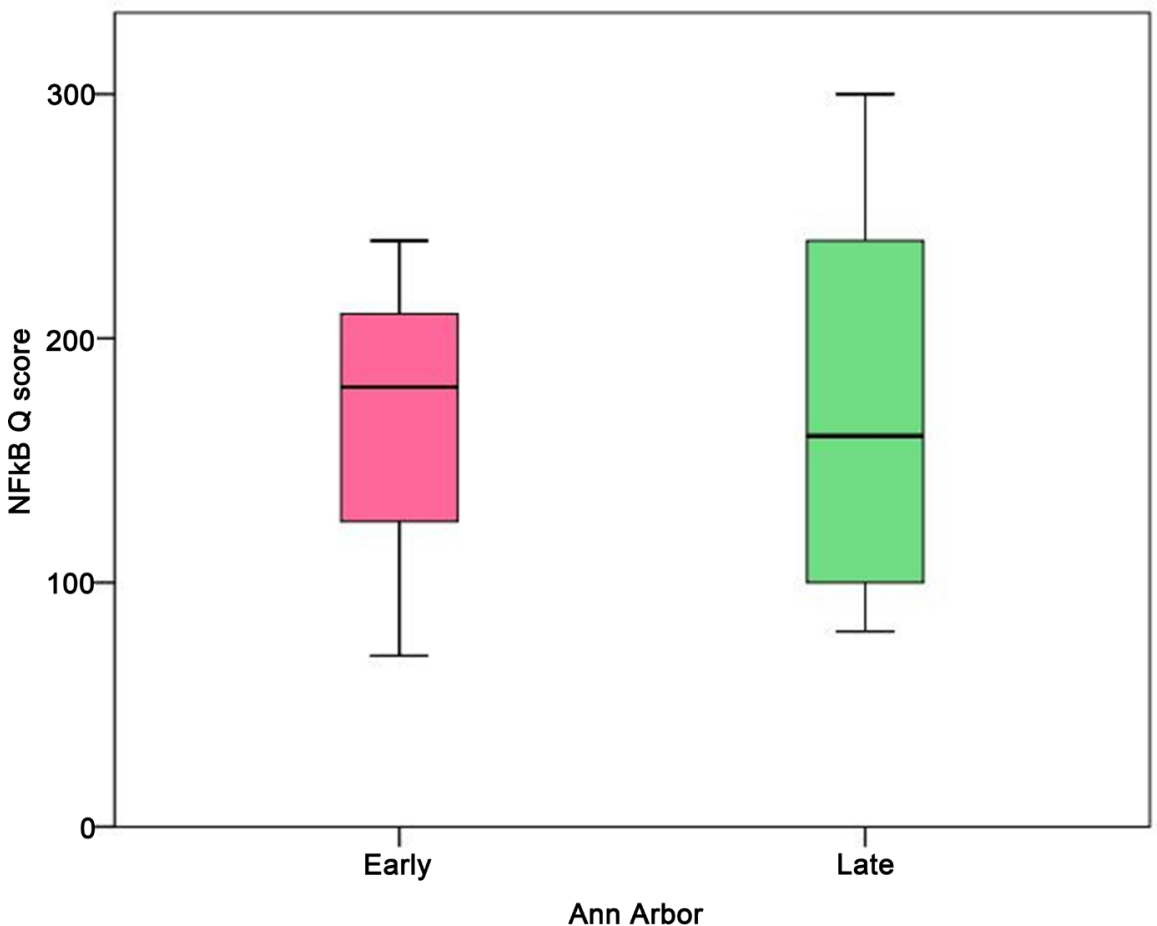

Figure 12. Relation between Ann Arbor staging and NF $\kappa$ B [p65] Q score. 
Albumin level. Among the patients with NF $\kappa \mathrm{B}$ [p65] Expression, the median of SGPT level in the HCV positive group was [Median 32.0] which is higher than in the HCV negative group [median 26.0], showing a statistically significant difference $[p=0.04]$. The median of SGOT level in the HCV positive group was [41.0 U/L] which is higher than in the HCV negative group [median $32.5 \mathrm{U} / \mathrm{L}$ ]. A positive correlation is present between Uric acid serum level and $\mathrm{NF} \kappa \mathrm{B}$ [p65] concentration. $[\mathrm{p}=0.060]$ High $\mathrm{LDH}$ was detected in HCV positive patients with $\mathrm{NF} \kappa \mathrm{B}$ [p65] expression with a percentage of $70 \%$ of cases, while in the HCV negative patients it was elevated in $62 \%$ of cases that expressed NF $\kappa B$ [p65].

Astatistically significant difference was detected among the HCV positive group with $\mathrm{NF} \kappa \mathrm{B}$ [p65] expression as regards response [p $=0.044]$. Overall response [CR + PR] was $63 \%$ in the HCV positive group, compared to $100 \%$ in the HCV negative group $[p=0.044]$ (Figure 13).

$\mathrm{NF} \kappa \mathrm{B}$ [p65] was expressed more in patient with no response to treatment in relation to patients with treatment response [either CR or PR] [mean $=230.0 \pm$ 61.64 vs mean $=156.0 \pm 71.49$, respectively].

\section{Discussion}

Many publications have described a difference in the clinical presentation and molecular biology between HCV-positive DLBCL patients and their HCV-negative counterparts [15]. In the present study we examined Cell of Origin [COO], $\mathrm{NF} \kappa \mathrm{B}$ [p65] expression, immunohistochemical and clinical characteristics in 30 patients with de novo DLBCL, in which 15 patients were Hepatitis C virus Positive with

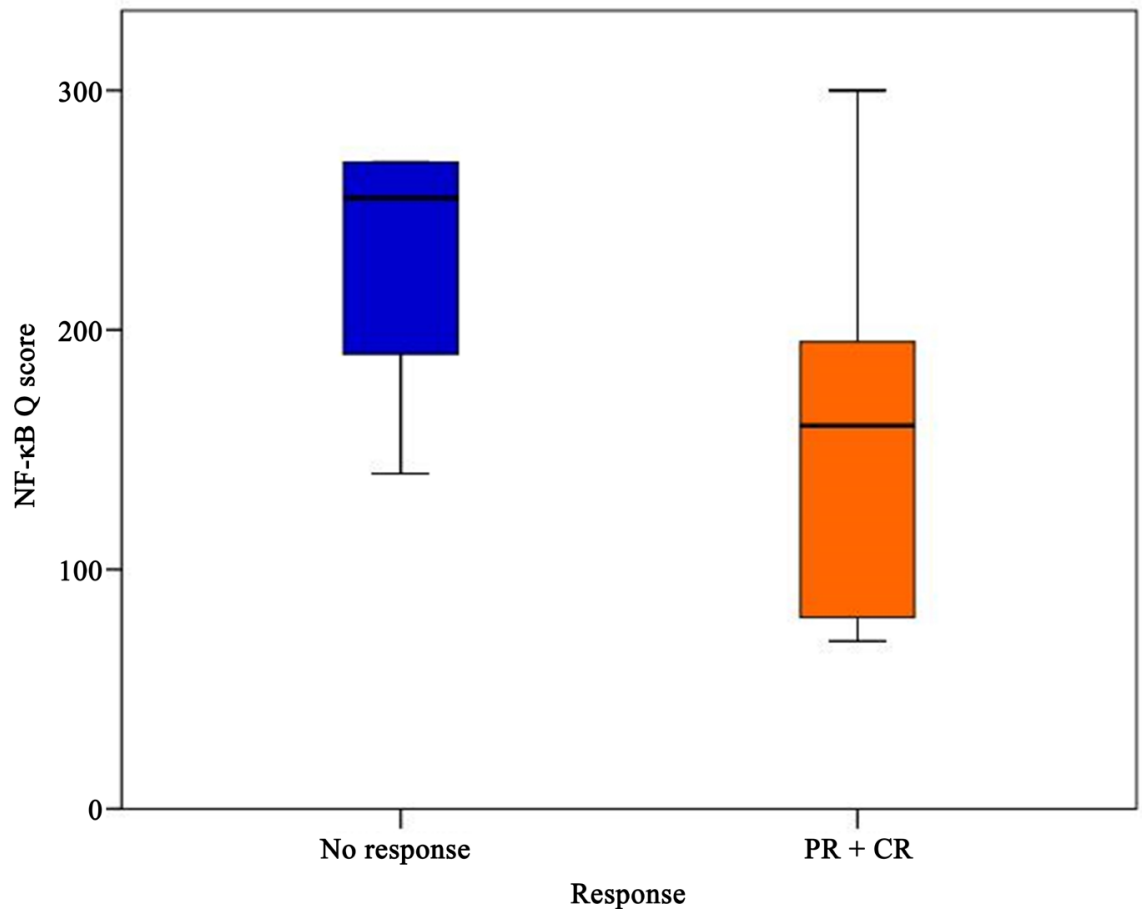

Figure 13. Relation between treatment response and NF $\kappa B$ [p65] Q score in patients with $\mathrm{NF} \kappa \mathrm{B}[\mathrm{p} 65$ ] expression in the total study group. 
genotype 4.

In the $\mathrm{HCV}$ positive group $73 \%$ of the cases expressed $\mathrm{NF} \kappa \mathrm{B}$ [p65] positivity $[\mathrm{n}=11]$. Meanwhile, in the HCV negative group, the NF $\kappa \mathrm{B}$ [p65] Expression was detected in $53.3 \%$ of the cases $[n=8]$. Meanwhile, in patients with $N F \kappa B$ [p65] expression, marked intensity in the $\mathrm{NF} \kappa \mathrm{B}$ [p65] IHC staining was detected in $63 \%$ of the HCV positive group, while it was seen in only $25 \%$ of the HCV negative group. NF $\kappa \mathrm{B}$ [p65] Expression was further examined for the concentration of positive cells in relation to the target population. In the HCV positive group, $27 \%$ showed expression between $30 \%-50 \%, 18.2 \%$ showed a concentration between $50 \%-70 \%$, and $47 \%$ was with a concentration of $70 \%$ and more, being the highest in the group.

Among the HCV positive group, $72 \%$ of the cases that expressed NF $\kappa \mathrm{B}$ [p65] were of the ABC subtype, and $27 \%$ of the cases were GCB. Two of them were of the Double positive [CD10+, MUM1+] group which mainly were associated with a relatively more inferior response to therapy. Besides they had a marked Intensity of $\mathrm{NF} \kappa \mathrm{B}$ [p65] staining, as well as a high $\mathrm{NF} \kappa \mathrm{B}$ [p65] concentration and Q score.

The viral load was positively correlated to the concentration of $\mathrm{NF} \kappa \mathrm{B}$ [p65], a median viral load of [41,500 ml] was detected among the group with a concentration [30\% - 50\%], a median of [308,500 ml] was among the group of [50\% - 70\%], and a higher viral load of $[1,158,500 \mathrm{ml}]$ was present in the group with more than $70 \%$ of $\mathrm{NF} \kappa \mathrm{B}$ [p65] concentration. There was a statistically non-significant positive correlation between $\mathrm{NF} \kappa \mathrm{B}$ [p65] intensity and $\mathrm{HCV}$ viral load in $\mathrm{HCV}$ positive group [ $\mathrm{n}=11][\mathrm{r}=0.538, \mathrm{p}=0.088]$.

$\mathrm{NF}-\kappa \mathrm{B}$ is involved in oncogenesis and is activated by a number of viral transforming proteins. In some cases, it is required for virus-induced malignant transformation [2]. In the present work, $\mathrm{NF} \kappa \mathrm{B}$ [p65] expression was found significantly increased in the HCV positive group. In addition, the HCV positive patients, NF $\kappa \mathrm{B}$ [p65] [intensity and concentration] and high viral load displayed a positive correlation. Thus that activation of canonical NF- $\kappa \mathrm{B}$ signaling pathway contributes to the development of HCV-associated B-NHL. Kasama et al. 2014 [5], Parvatiyar et al. 2010 [19], Castro et al. 2009 [20].

The higher frequency of $\mathrm{NF} \kappa \mathrm{B}$ [p65] expression among the HCV positive group found in the present study is consistent with the finding of Kasama et al., Gasztonyi et al. and Pikarsky et al., suggesting that $\mathrm{NF} \kappa \mathrm{B}$ [p65] activation occurs as a result of HCV infection and occurs in HCV related Lymphomas, which proposes a rationale to the increased risk of lymphogenesis seen in these patients.

In the present work, $\mathrm{NF} \kappa \mathrm{B}$ [p65] was positively expressed by immunohistochemistry in more than half of the study group, of which $73.3 \%$ were of the $A B C$ subgroup [ $\mathrm{p}=0.044]$. This is consistent with the findings of Kloo et al., Kasama et al. 2014 [5], Foureau et al. 2015 [21], Hallas et al. 2019 [22], Odqavist et al. [23], who have shown that constitutive activation of NF- $\kappa$ B is a common feature of ABC DLBCL cells [24]. The expression of nuclear factor kappa B/p65 in diffuse large $B$-cell lymphoma $A B C$ subtype was significantly higher than the GCB 
in the current study [11]. This study clarified the role of $\mathrm{NF} \kappa \mathrm{B}$ [p65] in $\mathrm{ABC}$ DLBCL and so aids in determining the subgroup of non-GCB DLBCL for which this pathway will serve as a valuable therapeutic target.

Although patients who expressed $\mathrm{NF} \kappa \mathrm{B}$ [p65] in this study had higher incidence of extranodal involvement, presented more in later stages [III + IV], and had higher LDH levels and IPI score, yet most of the patients had low ECOG score between 0 to 1 .

In reference to the relation of $\mathrm{NF} \kappa \mathrm{B}[\mathrm{p} 65]$ expression and treatment response, the overall response $[\mathrm{OR}]$ in patients with positive $\mathrm{NF} \kappa \mathrm{B}$ [p65] was $63 \%$, while it was $100 \%$ in the group that lacked $\mathrm{NF} \kappa \mathrm{B}$ [p65] expression [p $=0.04$ ], with a positive correlation with the $\mathrm{Q}$ score. Patient with progressive and stationary disease had a positive $\mathrm{NF} \kappa \mathrm{B}$ [p65] expression with higher Q scores. Wang et al. presented similar results in their study, showing that the negative $\mathrm{NF} \kappa \mathrm{B}[\mathrm{p} 65]$ group had a significantly better survival compared to the positive $\mathrm{NF} \kappa \mathrm{B}$ [p65] group. They suggested that that $\mathrm{NF} \kappa \mathrm{B}[\mathrm{p} 65]$ is an independent predictor of survival in high risk non-GCB DLBCL [11].

As regards the relation between [Cell of Origin] $\mathrm{COO}$ and $\mathrm{HCV}$, it was found that the $C R$ in the $A B C$ subgroup of the HCV positive patients was higher than the HCV negative group. Contrary to GCB, where the overall response rate [ORR] was found to be higher in the HCV negative group. An improvement of $\mathrm{ABC}$ outcome in the HCV positive group could be attributed to the administration of antiviral therapy simultaneous to chemotherapy.

The higher frequency of the $\mathrm{ABC}$ subtype exhibited intermediate to high viral load, while it was less in the GCB subtype. Among the cases that achieved CR or PR in both groups, low viral load was more prevalent. High HCV viral load presented with higher rates of No Response [Stationary disease and Progression]. This finding jusified the results of Merli et al. 2014 [25], Magnano et al. 2017 [26], which found that Base-line HCV-RNA load over $1000 \mathrm{KIU} / \mathrm{mL}$ was a virological parameter affecting OS in their study conducted in 2014.

Extranodal involvement was detected in $\mathrm{HCV}$ positive patients in $90 \%$ of patients in the present work. In which the spleen was the most common site of involvement $[p=0.003]$. Hepatic infiltration detected by imaging studies was found in $40 \%$ of cases. Besides, BM involvement was detected in $50 \%$ of patients which was statistically significant $[\mathrm{p}=0.02]$. Matching results were reported by Besson et al. 2006 [27] and Magnano et al. 2017 [26].

A highly significant increased incidence of thrombocytopenia $[\mathrm{P}=0.027]$ hypoprothrombinemia $[\mathrm{P}=0.001]$ and hypoalbumina $[\mathrm{p} \leq 0.001]$ in HCV-positive compared with HCV-negative patients was found. With a directly proportionate relationship with the viral load. Azzazi et al. 2017 [6], Ennishi et al. 2010 [28] have reported lower albumin level in HCV positive DLBCL and described this finding to be a predictor of inferior survival.

In HCV positive DLBCL, Directly Acting Antivirals [DAAs] could be introduced concomitantly with chemotherapy, to first eradicate the lymphogenetic trigger and also limit chemotherapy toxicity by decreasing the viral loadKloo et 
al. 2011 [29].

In the current study, the HCV negative group received R-CHOP, However the HCV positive group patients received simultaneous Directly Acting Antivirals [DAA], without rituximab. The complete response in the HCV positive group was higher than the HCV negative group. In a study performed by Halawani et al. 2017 [30], the HCV positive DLBCL group who received Chemotherapy without antiviral showed an inferior overall response in comparison with the current study. Hematological and gastroentestinal side effects to antivirals were mild and tolerable in this study, and none of the patients needed discontinuation of treatment.

The results of Tsutsumi et al., La Mura et al., and Merli et al., Montalto et al., Musto et al. concluded that the OR, PFS and OS of HCV positive DLBCL patients improved after consecutive administration of Antiviral Therapy [AVT] Iannitto et al. 2004 [31], Musto et al. 2005 [32]. Accordingly our findings suggest that simultaneous administration of DAAs in combination with chemotherapy disclosed a better response and less toxicity, validating this attractive integrated treatment strategy in the HCV positive DLBCL patients, consistent with Economides et al. [33].

\section{Conclusions}

HCV lymphogenesis represents a fascinating model of cellular transformation including chronic antigenic stimulation and direct transformation by viral proteins. The canonical $\mathrm{NF} \kappa \mathrm{B}$ [p65] pathway is considered an important factor concerning the HCV positive DLBCL. In the present work The NF $\kappa B$ [p65] disclosed an increased expression in HCV positive DLBCL compared to HCV negative group, and expressed more frequently in $\mathrm{ABC}$ than in GCB subtypes. Expression of $\mathrm{NF} \kappa \mathrm{B}$ [p65] is associated with poor response to therapy in DLBCL.

Although previous works have correlated the viral load with other markers of hepatic inflammation in lymphoma, yet they did not correlate it with the NF $\kappa \mathrm{B}$ [p65] expression. Based on the current study, a positive correlation between $\mathrm{NF} \kappa \mathrm{B}$ [p65] and viral load was found in Egyptian patients with genotype [4].

In addition DAA based antiviral therapy simultaneous with CHOP has demonstrated promising results in the HCV DLBCL group of patients, with no considerable toxicity. However it is of importance to well define the HCV DLBCL pathogenesis in order to guide futuristic therapeutic decisions.

\section{Conflicts of Interest}

The authors declare no conflicts of interest regarding the publication of this paper.

\section{References}

[1] Zhang, B., Calado, D.P., Wang, Z., Fröhler, S., Köchert, K., Qian, Y., et al. (2015) An Oncogenic Role for Alternative NF- $\kappa$ B Signaling in DLBCL Revealed upon Deregulated BCL6 Expression. Cell Reports, 11, 715-726. 
https://doi.org/10.1016/j.celrep.2015.03.059

[2] Escárcega, R.O., Fuentes-Alexandro, S., García-Carrasco, M., Gatica, A. and Zamora, A. (2007) The Transcription Factor Nuclear Factor-Kappa B and Cancer. Clinical Oncology, 19, 154-161. https://doi.org/10.1016/j.clon.2006.11.013

[3] Perkins, N.D. (2007) Integrating Cell-Signalling Pathways with NF- $\kappa$ B and IKK Function. Nature Reviews Molecular Cell Biology, 8, 49-62. https://doi.org/10.1038/nrm2083

[4] Liu, T., Zhang, L., Joo, D. and Sun, S.-C. (2017) NF- $\kappa$ B Signaling in Inflammation. Signal Transduction and Targeted Therapy, 2, Article No. 17023.

https://doi.org/10.1038/sigtrans.2017.23

[5] Kasama, Y., Mizukami, T., Kusunoki, H., Peveling-Oberhag, J., Nishito, Y., Ozawa, M., et al. (2014) B-Cell-Intrinsic Hepatitis C Virus Expression Leads to B-CellLymphomagenesis and Induction of NF- $\kappa$ B Signalling. PLoS ONE, 9, e91373. https://doi.org/10.1371/journal.pone.0091373

[6] Azzazi, M., Mohamed, M., Mousa, M., Mohammed, R. and Eldin Youssef, S. (2017) Multicentre Study of Hepatitis C Virus Status in Egyptian Patients with B-Cell Non-Hodgkin's Lymphoma with Assessment of Patients' Immunological State. The Egyptian Journal of Haematology, 42, 19-30. https://doi.org/10.4103/1110-1067.206435

[7] Mele, A., Pulsoni, A., Bianco, E., Musto, P., Szklo, A., Sanpaolo, M.G., et al. (2003) Hepatitis C Virus and B-Cell Non-Hodgkin Lymphomas: An Italian Multicenter Case-Control Study. Blood, 102, 996-999.

https://doi.org/10.1182/blood-2002-10-3230

[8] Rajalakshmy, A.R., Malathi, J. and Madhavan, H.N. (2014) HCV Core and NS3 Proteins Mediate Toll Like Receptor Induced Innate Immune Response in Corneal Epithelium. Experimental Eye Research, 128, 117-128. https://doi.org/10.1016/j.exer.2014.09.011

[9] Dondelinger, Y., Aguileta, M.A., Goossens, V., Dubuisson, C., Grootjans, S., Dejardin, E., et al. (2013) RIPK3 Contributes to TNFR1-Mediated RIPK1 Kinase-Dependent Apoptosis in Conditions of cIAP1/2 Depletion or TAK1 Kinase Inhibition. Cell Death \& Differentiation, 20, 1381-1392.https://doi.org/10.1038/cdd.2013.94

[10] Torka, P., Hernandez-Ilizaliturri, F.J., Belliotti, S., Mavis, C., Gu, J. and Czuczman, M.S. (2014) Inhibition of Nuclear Factor Kappa B (NF $\kappa$ B)/Interferon Regulatory Factor 4 (IRF4) Signaling Pathway in Activated B-Cell (ABC) Diffuse Large B-Cell Lymphoma (DLBCL) by Combining MLN4924, a Novel NEDD8 Activating Enzyme Inhibitor (NAE) and Ibrutinib. Blood, 124, 1768.

[11] Wang, J., Zhou, M., Zhang, Q.-G., Xu, J., Lin, T., Zhou, R.-F., et al. (2017) Prognostic Value of Expression of Nuclear Factor Kappa-B/p65 in Non-GCB DLBCL Patients. Oncotarget, 8, 9708-9716. https://doi.org/10.18632/oncotarget.14182

[12] Schneider, C., Pasqualucci, L. and Dalla-Favera, R. (2011) Molecular Pathogenesis of Diffuse Large B-Cell Lymphoma. Seminars in Diagnostic Pathology, 28, 167-177. https://doi.org/10.1053/j.semdp.2011.04.001

[13] Mudaliar, M.A.V., Haggart, R.D., Miele, G., Sellar, G., Tan, K.A.L., Goodlad, J.R., et al. (2013) Comparative Gene Expression Profiling Identifies Common Molecular Signatures of NF- $\kappa$ B Activation in Canine and Human Diffuse Large B Cell Lymphoma (DLBCL). PLoS ONE, 8, e72591. https://doi.org/10.1371/journal.pone.0072591

[14] Peveling-Oberhag, J., Arcaini, L., Bankov, K., Zeuzem, S. and Herrmann, E. (2016) The Anti-Lymphoma Activity of Antiviral Therapy in HCV-Associated B-Cell 
Non-Hodgkin Lymphomas: A Meta-Analysis. Journal of Viral Hepatitis, 23, 536-544. https://doi.org/10.1111/jvh.12518

[15] Swerdlow, S.H., Campo, E., Pileri, S.A., Harris, N.L., Stein, H., Siebert, R., et al. (2016) The 2016 Revision of the World Health Organization Classification of Lymphoid Neoplasms. Blood, 127, 2375-2390. https://doi.org/10.1182/blood-2016-01-643569

[16] Peveling-Oberhag, J., Arcaini, L., Hansmann, M.-L. and Zeuzem, S. (2013) Hepatitis C-Associated B-Cell Non-Hodgkin Lymphomas. Epidemiology, Molecular Signature and Clinical Management. Journal of Hepatology, 59, 169-177. https://doi.org/10.1016/j.jhep.2013.03.018

[17] Kohli, A., Kapoor, R., Sims, Z., Nelson, A., Sidharthan, S., Lam, B., et al. (2015) Ledipasvir and Sofosbuvir for Hepatitis C Genotype 4: A Proof-of-Concept, Single-Centre, Open-Label Phase 2a Cohort Study. The Lancet Infectious Diseases, 15, 1049-1054. https://doi.org/10.1016/S1473-3099(15)00157-7

[18] Hans, C.P., Weisenburger, D.D., Greiner, T.C., Gascoyne, R.D., Delabie, J., Ott, G., et al. (2004) Confirmation of the Molecular Classification of Diffuse Large B-Cell Lymphoma by Immunohistochemistry Using a Tissue Microarray. Blood, 103, 275-282. https://doi.org/10.1182/blood-2003-05-1545

[19] Parvatiyar, K., Barber, G.N. and Harhaj, E.W. (2010) TAX1BP1 and A20 Inhibit Antiviral Signaling by Targeting TBK1-IKKi Kinases. The Journal of Biological Chemistry, 285, 14999-15009. https://doi.org/10.1074/jbc.M110.109819

[20] Castro, I., Wright, J.A., Damdinsuren, B., Hoek, K.L., Carlesso, G., Shinners, N.P., et al. (2009) B Cell Receptor-Mediated Sustained c-Rel Activation Facilitates Late Transitional B Cell Survival through Control of B Cell Activating Factor Receptor and NF- $\kappa$ B2. The Journal of Immunology, 182, 7729-7737.

https://doi.org/10.4049/jimmunol.0803281

[21] Foureau, D., Druhan, L.J., Steuerwald, N.M., Baxter, S.A., Fasan, O.O., Avalos, B.R., et al. (2015) Cytokine Profiling of ABC-Subtype and GCB-Subtype Diffuse Large B Cell Lymphoma: Systemic NF $\kappa$ B Activation and Impact on Myeloid-Derived Suppressor Cells Distribution. Blood, 126, 2666.

[22] Hallas, C., Preukschas, M. and Tiemann, M. (2019) Immunohistochemical Distinction of ABC and GCB in Extranodal DLBCL Is Not Reflected in Mutation Patterns. Leukemia Research, 76, 107-111. https://doi.org/10.1016/j.leukres.2018.10.003

[23] Foureau, D., Druhan, L.J., Steuerwald, N.M., Baxter, S.A., Fasan, O.O., Avalos, B.R. and Ghosh, N. (2015) Cytokine Profiling of ABC-Subtype and GCB-Subtype Diffuse Large B Cell Lymphoma: Systemic Nfkb Activation and Impact on Myeloid-Derived Suppressor Cells Distribution. Blood, 126, 2666.

[24] Kloo, B., Nagel, D., Pfeifer, M., et al. (2010) C role of P Signaling for N Survival in a Subset of Activated B Diffuse Large B Lymphoma Cells. Proceedings of the National Academy of Sciences of the United States, 108, 272-277. https://doi.org/10.1073/pnas.1008969108

[25] Merli, M., Visco, C., Spina, M., Luminari, S., Ferretti, V.V., Gotti, M., et al. (2014) Outcome Prediction of Diffuse Large B-Cell Lymphomas Associated with Hepatitis C Virus Infection: A Study on Behalf of the Fondazione Italiana Linfomi. Haematologica, 99, 489-496. https://doi.org/10.3324/haematol.2013.094318

[26] Magnano, L., Balague, O., Dlouhy, I., Rovira, J., Karube, K., Pinyol, M., et al. (2017) Clinicobiological Features and Prognostic Impact of Diffuse Large B-Cell Lymphoma Component in the Outcome of Patients with Previously Untreated Follicular Lymphoma. Annals of Oncology, 28, 2799-2805. 
https://doi.org/10.1093/annonc/mdx407

[27] Besson, C., Canioni, D., Lepage, E., Pol, S., Morel, P., Lederlin, P., et al. (2006) Characteristics and Outcome of Diffuse Large B-Cell Lymphoma in Hepatitis C Virus-Positive Patients in LNH 93 and LNH 98 Groupe d'Etude des Lymphomes de l'Adulte Programs. Journal of Clinical Oncology, 24, 953-960. https://doi.org/10.1200/JCO.2005.01.5016

[28] Ennishi, D., Maeda, Y., Niitsu, N., Kojima, M., Izutsu, K., Takizawa, J., et al. (2010) Hepatic Toxicity and Prognosis in Hepatitis C Virus-Infected Patients with Diffuse Large B-Cell Lymphoma Treated with Rituximab-Containing Chemotherapy Regimens: A Japanese Multicenter Analysis. Blood, 116, 5119-5125. https://doi.org/10.1182/blood-2010-06-289231

[29] Kloo, B., Nagel, D., Pfeifer, M., Grau, M., Duwel, M., Vincendeau, M., et al. (2011) Critical Role of PI3K Signaling for NF- $\kappa$ B-Dependent Survival in a Subset of Activated B-Cell-Like Diffuse Large B-Cell Lymphoma Cells. Proceedings of the National Academy of Sciences of the United States of America, 108, 272-277. https://doi.org/10.1073/pnas.1008969108

[30] El-Halawani, N., Nazir, A., Mashali, N., Sorour, A. and Moussa, M.A. (2017) The Diagnostic and Prognostic Impact of Serum miRNA-21 in a Sample of Hepatitis C/None Hepatitis Diffuse Large B Cell Lymphoma Egyptian Patients. American Journal of Molecular Biology, 7, 49-72. https://doi.org/10.4236/ajmb.2017.71005

[31] Iannitto, E., Ammatuna, E., Tripodo, C., Marino, C., Calvaruso, G., Florena, A.M., et al. (2004) Long-Lasting Remission of Primary Hepatic Lymphoma and Hepatitis C Virus Infection Achieved by the $\alpha$-Interferon Treatment. Journal of Hematology, 5, 530-533.

[32] Musto, P., Dell'Olio, M., La Sala, A., Mantuano, S. and Cascavilla, N. (2005) Diffuse B-Large Cell Lymphomas (DBLCL) with Hepatitis-C Virus (HCV) Infection: Clinical Outcome and Preliminary Results of a Pilot Study Combining R-CHOP with Antiviral Therapy. Blood, 106, 2447.

[33] Economides, M.P., Mahale, P., Kyvernitakis, A., Turturro, F., Kantarjian, H., Naing, A., Hosry, J., Shigle, T.L., Kaseb, A. and Torres, H. (2016) Concomitant Use of Direct-Acting Antivirals and Chemotherapy in Hepatitis C Virus-Infected Patients with Cancer. Alimentary Pharmacology \& Therapeutics, 44, 1235-1241.

https://doi.org/10.1111/apt.13825 